\title{
The bionomic of road users: a new perspective of individual mobility approach
}

\author{
Pranoto Dirhan Putra ${ }^{1,}$ Sri Rum Giyarsih ${ }^{2}$, and Djaka Marwasta ${ }^{2 *}$ \\ ${ }^{1}$ Faculty of Engineering, Atma Jaya Yogyakarta University, 55281. Sleman, Yogyakarta, Indonesia \\ ${ }^{2}$ Faculty of Geography, Universitas Gadjah Mada, 55281, Sleman, Yogyakarta, Indonesia
}

\begin{abstract}
Mostly, transport studies are centered on the factors of transportation rather than human movements. In a similar vein, communication technology revolution influence to people mobility. The performance of traffic pattern does not tend to deliver utmost needs of people mobility, because less attention of the substance of inhabitant movements. The importance of bionomic patterns of road users is based on the fact that behavior approach and adaptation will create pattern of people mobility. The aim of this research is to determine whether they adapt to nearby environment or not. Taking this, variables surveyed are individual attribute, time, duration, location, vehicle, communication to transport and purpose of trips. Investigation is conducted by providing questionnaire. The main result of this study are that the bionomic pattern of road users of selected population shows that they prefer to use simple mode vehicle to transport such as motor bike and walking. Moreover, these choices are preferred to be taken as a response to higher dense of traffic population and worsen road network system. It would be wise for planning if it considers potential effect not only to traffic but also regular road users need including goods supply, proper access and facilities for unmotorized vehicle.
\end{abstract}

\section{Introduction}

Mobility has been facing new challenges even when most of cities are still growing and technology is surely rounding into rapid-continuous advancement [1], [2], [3]. Indeed, individual movements are being more random in time and more countless destinations [4]. Also, albeit the slogan of reducing energy consumption and pollution has declared in many countries by generating sustainable transport, the quality of mobility of persons or groups in road networks of towns is obviously far from environmentally sound [5].

Then again, most of transport studies are focused on the elements of transportation rather than "something" substance that create human movements such as traffic [6], city planning [7] and computer modelling [8], [9], [10]. In line with this, global development in communication technology obviously gives a new role to people mobility [11], [12], [13], [14] Since then, this transformation has produced mobility which is more casual and faster [15].

Nevertheless, road, which was intended to connect various hierarchy of needs, has become a kind of disaster instead of supporting it, [16], [17], [18], [19], [20].

\footnotetext{
* Corresponding author: jakamar@ugm.ac.id
}

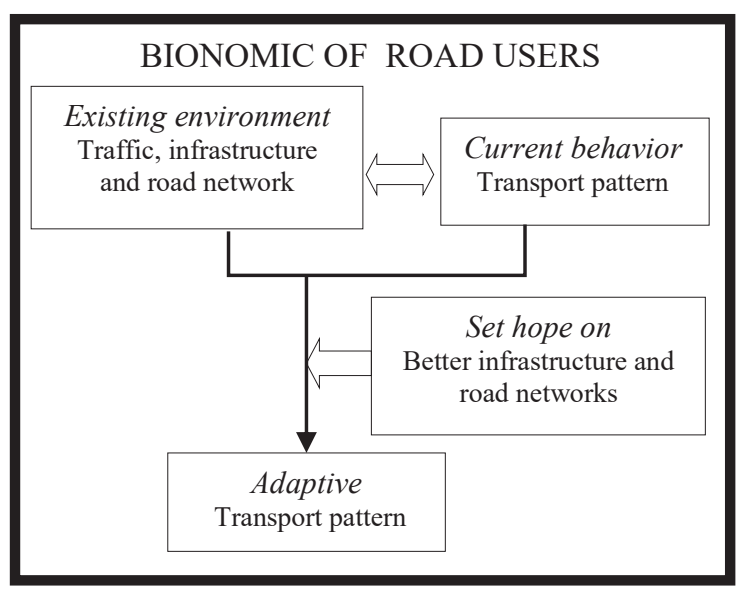

Source: [40]

Fig. 1. The concept of bionomic due to this study

Back an argument to bionomic, this idea responds to reality that today's human mobility is more random and technology-oriented as depicted in Figure 2 [21]. It illustrates something like transformation of networks planning from setting distance to computer modelling. In addition, higher growth vehicle population in most of global cities has given impact on more complex traffic disruption, increasing pollution dan rising delay [22], [14], [12]. Thus, this occurrence should be anticipated using appropriate planning approach for better future environment [23]. Subjects linked to transportation are more individuals and more various [24]. So, behavior of 
road users, which is defined as a result of adaptation to environment, is obviously in line to be investigated deeper.

\section{Research Problem}

Nowadays, the performance of traffic pattern does not tend to deliver utmost needs of people mobility [25], [26]. This perhaps occur because less attention of the substance of inhabitant movements such as the bionomic of road users. In addition, this phenomenon may also happen as the presence of the gap between transportation required by society and the existence of infrastructure [27] (lrawati, et al., 2012).

Therefore, the importance of bionomic patterns of road users is based on the fact that behavior approach and adaptation will create something like core pattern of people mobility [28], [29]. Figure 1 displays the idea of bionomic approach for road users which is purposed in this study. This is initiated by the actual circumstance that most of road users hope for better infrastructure and road networks despite there is a gap between existing infrastructure and various individual behavior [28]. The interaction among the three elements of these will produce adaptation as a respond to them.

The main aim of this survey is delivering questions to determine whether they adapt to nearby environment or not. Taking this, variables surveyed are individual attribute, time, duration, location, vehicle, communication to transport and purpose of trips. Investigation is conducted by providing questionnaire.

\section{Research Methods}

Selected residents to be studied is population who stay in Condongcatur village, Depok Subdistrict, Sleman Regency, Special Region of Yogyakarta, Indonesia. Sample's age is chosen in between 17 to 60 years old. This is assumed that they tend to take destination and route more independent rather than out of selected age range. Also, this productive oldness tends to transport intended for fulfill daily needs. It might be because better physical condition and career opportunity. This age range is classified into four groups which are 1725years old, 26-35 years old, 36-45 years old and 45-60 years old. Number of samples taken is 80 inhabitants

Data, then, plotting into graphs so as to determine the features of road users in relation to their adaptation to infrastructure environment. At this point, the bionomic of them can be interpreted by comparing among charts.

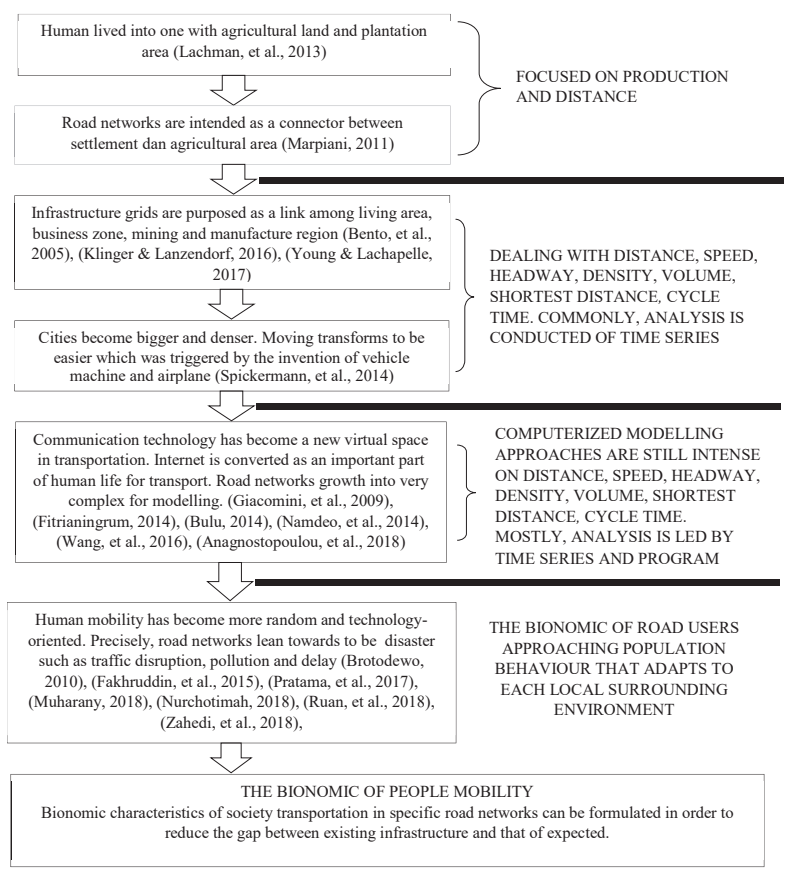

Source: [40]

Fig. 2. The argument for the standing of bionomic of road users related to this study

\section{Literature Reviews}

The outline of human bionomic is clearly associated with social effort to fulfill essential needs of living and the process to achieve it [31]. Along with the worldwide development of cities, transportation has taken major influence on quality of life [32], [14] (Zahedi, et al., 2018; Lai, 2018). Presently, the crossing point among both of them is becoming more crucial as described in Figure 3 that shows the layout between individuals, transportation and destination purposes [33], [34].

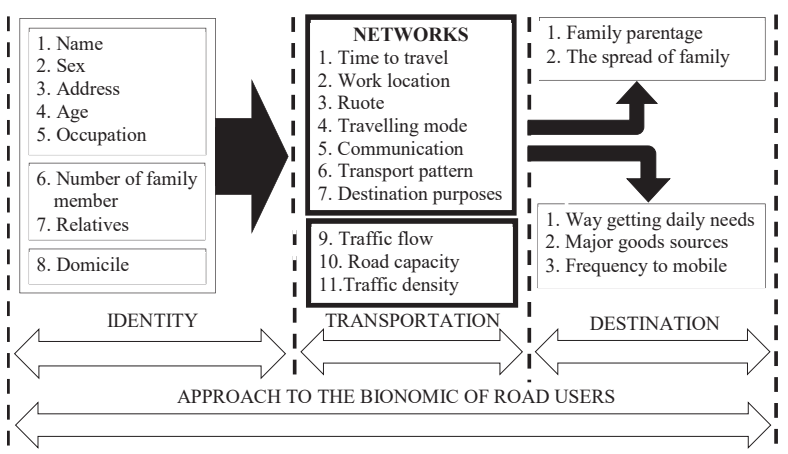

Source: [40]

Fig. 3 modification of the bionomic approach of road users

This figure can be construed that wider such problems of networks and its components, bigger gap between individual demand and journey's end [35], [36], [37]. Also, it explains that nowadays networks and transportation has taken over a key role for society

and towns with the intention most of living rudiments such as travelling cost, time, energy and environment impact [38], [39], [41] (Conway, et al., 2019; Mahauta \& 
Andrieub, 2019; Gusnita, 2010). Concerning this, investigation slightly starts on the portray of selected family characteristics.

\section{Results and Discussion}

Families inside this particular study area have between zero to six children which is $4.5 \%, 14.8 \%$, $38.6 \%, 18.2 \%, 15.9 \%, 4.5 \%$ and $3.4 \%$ respectively as shown in Figure 4. Whereas, Figure 5 represents the percentage of family member in range of 2 members (9.1\%), 3 members $(11.4 \%), 4$ members $(44.3 \%), 5$ members $(18.2 \%), 6$ members $(10.2 \%), 7$ members $(4.5 \%)$ and 8 members $(2.3 \%)$. While, most of respondent ages are $46-65$ years $(77.3 \%)$ and the rest is at the age of $36-45$ years $(21.6 \%), 26-35$ years $(1.1 \%)$ as displayed in Figure 6. But there is no respondent with age interval of $17-25$ years $(0.0 \%)$.

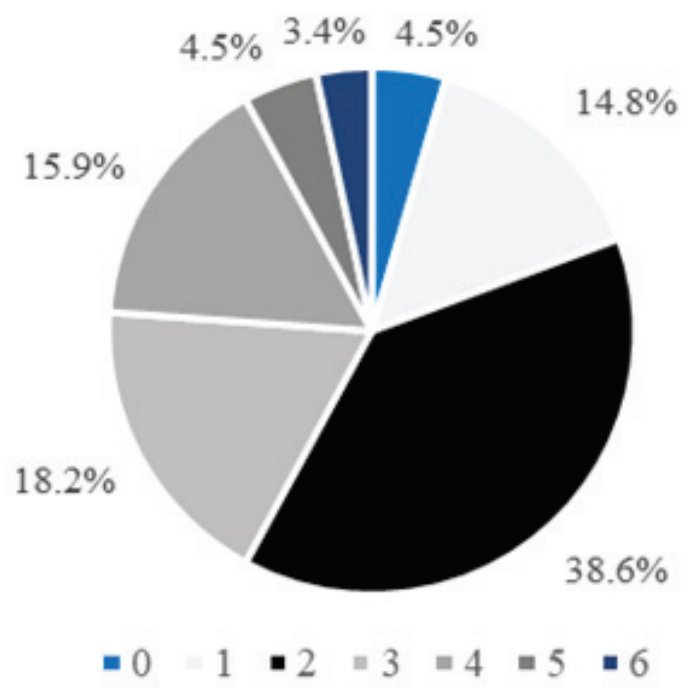

Source: [40]

Fig. 4 Percentage of number of children

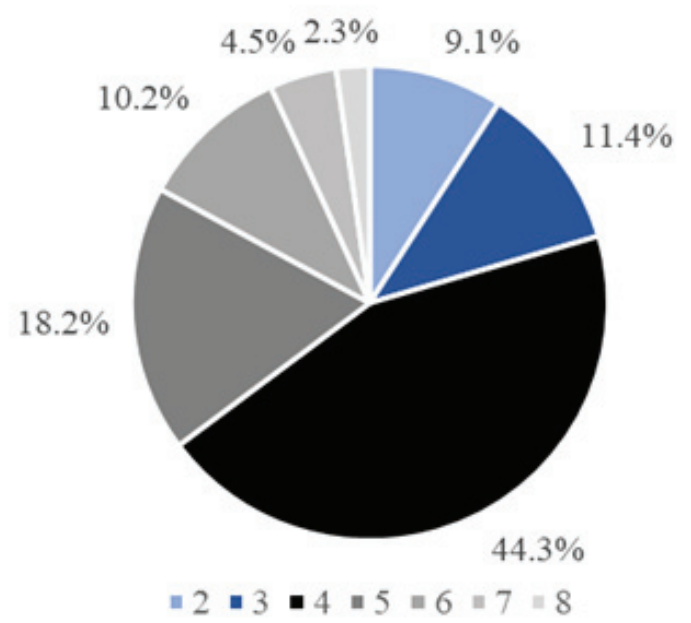

Source: [40]

Fig. 5 Percentage of family member

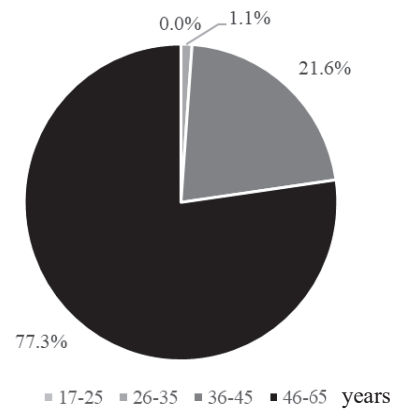

Source: [40]

Fig. 6 Percentage of respondent age

Resident occupation is categorized into labor (19.3\%), seller $(2.3 \%)$, farmer $(1.1 \%)$, private business $(50.0 \%)$, house wife $(4.5 \%)$, retired $(8.0 \%)$, public officer $(6.8 \%)$ and unemployed $(8.0 \%)$ as shown in Figure 7.

Whereas, most of respondents $(89,8 \%)$ are coming from selected study area or, in other words, they are not moving to other cities for living. Home town of inhabitants is displayed in Figure 8. Likewise, these majority samples have relatives who are living in the same area $(75.0 \%)$ as shown in Figure 9.
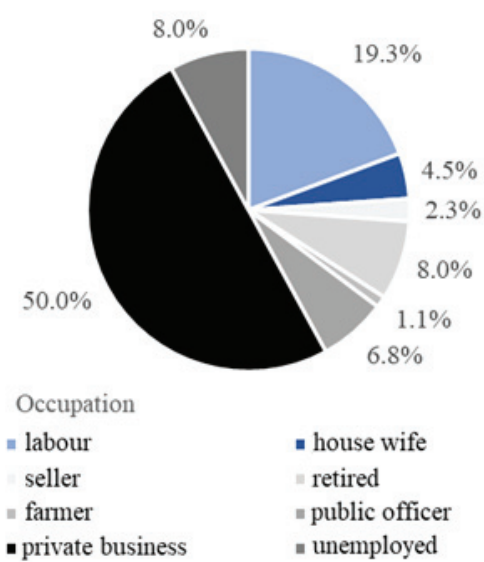

Source: [40]

Fig. 7 Percentage of respondent occupation

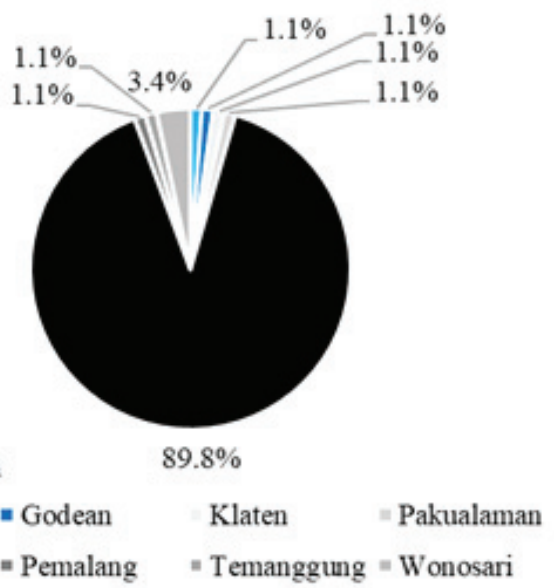

Source: [40]

Fig. 8 Percentage of respondent;s home town 


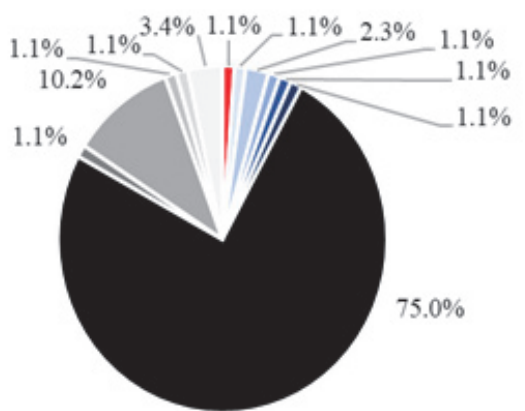

Region where lative living

$\begin{array}{llll}\text { - Deresan } & \text { Godean } & \text { "Kendari } & \text { " Klaten } \\ \text { - Kota Yogya } & \text { - Magelang } & \text { - Pandeyan } & \text { " Pemalang } \\ \text { " Sleman } & \text { "Solo } & \text { "Temanggung } & \text { Wonosari }\end{array}$

Source: [40]

Fig. 9 Percentage of respondent native living

Distribution type of sources for primary commodity that respondents usually visit are traditional market (17.8\%), modern market $(20.1 \%)$, home market $(21.1 \%)$, self-service market $(20.4 \%)$, supermarket $(20.1 \%)$ and others $(0.5 \%)$ as revealed in Figure 10 . This distribution, which is almost comparable for all market, may occur because they are located close to the village although respondents confront with higher dense traffic. Yet, regarding to Figure 11, home market is the most place visited by locals $(18.9 \%)$ for every day shopping following by traditional market $(2.8 \%)$, self-service market $(2.3 \%)$, super market $(0.3 \%)$ and other $(0.3 \%)$. But, in unplanned schedule scale, modern market is the most visited by residents $(19.9 \%)$ continued by supermarket (18.6\%), self-service market $(15.9 \%)$, traditional market (14.6\%) and home market (2.0\%).

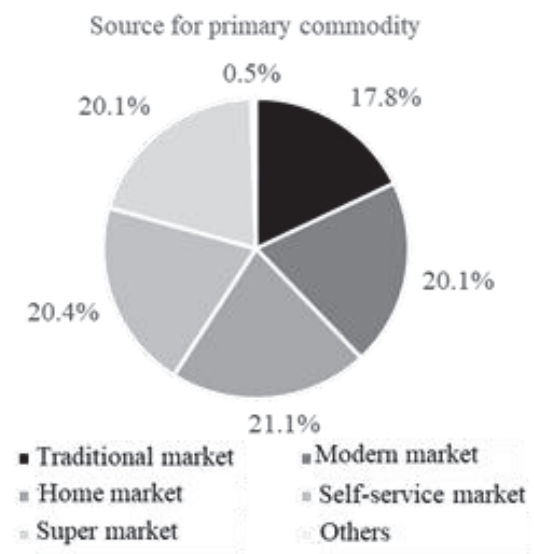

Source: [40]

Fig. 10 Source for primary commodity

Opposing phenomena between home market which is most visited daily and modern market which is visited without day (Figure 10 and Figure 11) shows that there is a kind of obstacle that probably tends to reduce people's ability to reach them. This is in line with the presumptively stated in Figure 3 that road networks have a tendency to be such as barrier for users.

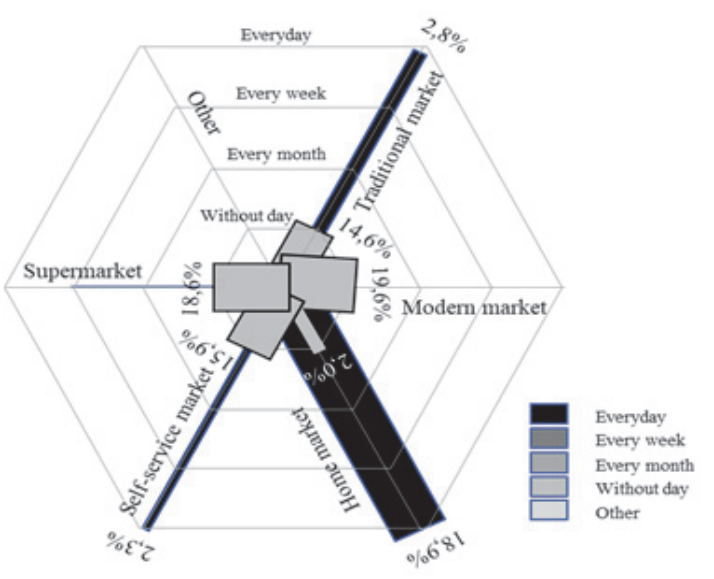

Source: [40]

Fig. 11 Distribution frequency of visiting source for primary commodity

Next, motor cycle is the most favorite vehicle for riding $(40.8 \%)$ following by walking $(31.2 \%)$, bicycle $(23.6 \%)$ and car $(4.5 \%)$ as portrayed in Figure 12. Surprisingly, none of the respondent takes public transport for travelling despite of proper mass transport passing by surrounding their living area. Again, disreputable road networks could be charged with as casual factor in this occurrence.

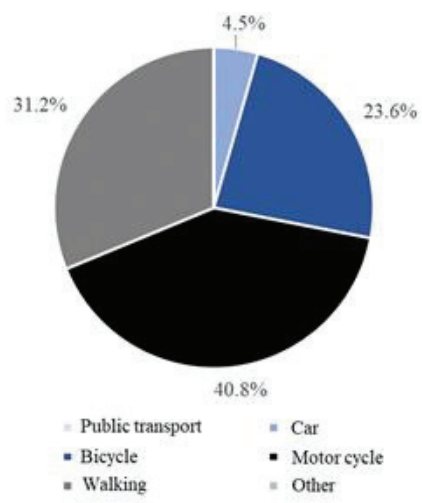

Source: [40]

Fig. 12 Proportion of transport mode using by inhabitants

Ensuing, travelling purpose is dominated finding food $(21.5 \%)$ at around 12.00 p.m. that is followed by work reason $(9.8 \%)$ at around 06.00 a.m. and recreation $(0.8 \%)$ at about $06.00 \mathrm{a} . \mathrm{m}$. as revealed in Figure 13. This diagram clearly shows distribution pattern of resident movement versus time to do such things. Shortly, there is three critical periodic time which is 06.00-07.00 a.m., 12.00-13.00 p.m. and 18.00-19.00 a.m. local time.

Similar way, regarding to Figure 14, there is evidence that walking at the period of 12.00-13.00 p.m. is the highest proportion (17.5\%) following by the same mode of transport at 18.00-19.00 p.m. (15.3\%). The second biggest favorite mode is motor cycle $(8.5 \%)$ at 07.00-08.00 a.m. It can be questioned why they prefer to choose these two modes of transport in their routine activities even so better means of carriage is basically available. It perhaps occurs in respond to the condition of worsen traffic situation and degraded performance of infrastructure. Although it might more than one motive, then again, there is mark that local road users obviously adapt their environment and adjust their behavior. 


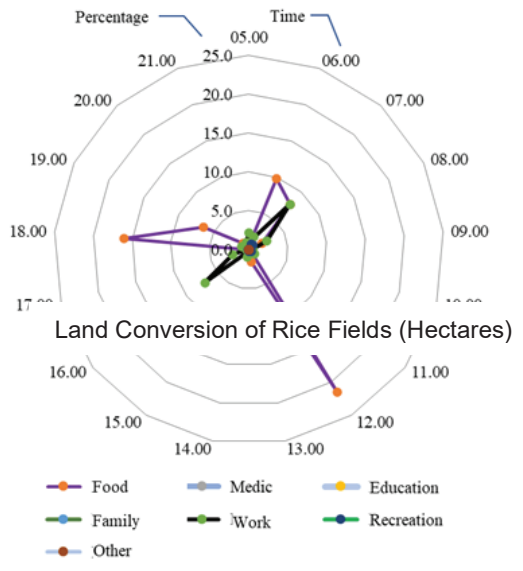

Source: [40]

Fig. 13. distribution of travelling purposes from Monday to Sunday

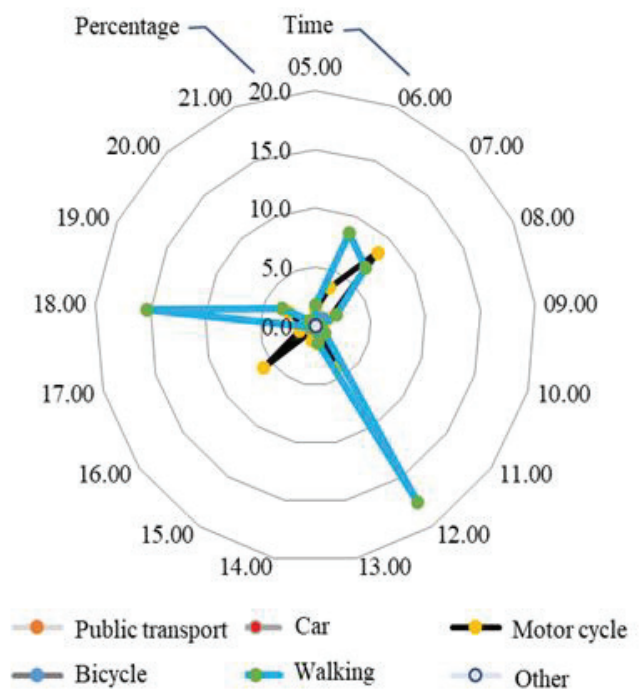

Source: [40]

Fig. 14. Proportion of transport mode from Monday to Sunday

It can be clearly construed form Figure 13 and Figure 14 that respondents tend to have both similar pattern of travelling purposes for activities and similar pattern mode for moving if we look it deeper related to time which is $06.00-07.00,12.00-13.00$ and 18.00-19.00 local time. Combining data collected above, it can be summarized that road users have bionomic characteristic as an outcome of adaptation to their environment that form unique behavior.

\section{Conclusion}

Finally, the bionomic pattern of road users of selected population in this study shows that they prefer to use simple mode vehicle to transport such as motor bike and walking. Also, this is taken in favorite of time at 06.00-07.00, 12.00-13.00 and 18.00-19.00 local time. Moreover, these choices are preferred to be taken as a response to higher dense of traffic population and worsen road network system. Therefore, most of them favor home market to fulfill their need for primary goods rather than other market.

As a suggestion, it would be wise for planning if it considers potential effect not only to traffic but also regular road users need including goods supply, proper access and facilities for unmotorized vehicle (Putra, 2021).

\section{Acknowledgment}

This paper is a tad part of dissertation which is entitled The Bionomic Approach of Transport Users in Road Network System. This research is funded with RTA (Rekognisi Tugas Akhir) grant scheme of UGM year 2021. It is written by the first author under a good hand supervision of second author and marvelous guidance of third author. It is innumerable thanks for all sage reviewers who has delivered prudently suggestions in order to be the pink of perfection of this paper.

\section{References}

1. Mustafa, A., Analisis Permasalahan Kinerja Jaringan Jalan Kota Yogyakarta Pada Saat Liburan Dan Usulan Pemecahannya. Yogyakarta: Perpustakaan Pusat UGM (2016)

2. Deng, Y. \& Srinivasan, S., Urban Land Use Change and Regional Access: A Case Study in Beijing, China. Habitat International, Volume 51, February 2016, pp. 103-113 (2016)

3. McCan, B., Completing Our Streets, The Transition to Safe and Inclusive Transportation Networks. The Center for Resource Economics (2013)

4. Brownleea, A. E. et al., A Fuzzy Approach To Addressing Uncertainty In Airport Ground Movement Optimisation. Transportation Research Part C, Volume 92 (2018), p. 150-175(2018)

5. Azizalrahman, H. \& Hasyimi, V., A Model for Urban Sector Drivers of Carbon Emissions. Sustainable Cities and Society, Volume 44, January 2019, pp. 46-55 (2019)

6. Guo, F., Polak, J. W. \& Krishnan, R., Predictor Fusion for Short-Term Traffic Forecasting. Transportation Research, Volume Part C 92 (2018), p. 90-100 (2018)

7. Dejeammes, M., Urban Mobility Plans and Accessibility. Journal of Transport and Land Use, Volume 2, No. 2 (Spring 2009),, pp. 67-78 (12 pages) (2009)

8. Felician, C., H. M. \& Nishinari, K., Correction: A Universal Function for Ccapacity of Bidirectional Pedestrian Streams: Filling The Gaps in The Literature. PLoS ONE, Volume 4(4):e0216314 • April 2019 (2019)

9. Yu, H., Tseng, H. E. \& Langaria, R., A Human-Like Game Theory-Based Controller For Automatic Lane Changing. Transportation Research, Volume Part C 88 (2018), p. 140-158 (2018) 
10. Febrianda, Y., Mahmudah, N. \& Muchlisin, Pemodelan Lalu Lintas Mengunakan PKJI 2014 Dan SoftwareVissim 9 pada Simpang APILL Madukismo, Ring Road Selatan, Yogyakarta. Yogyakarta: Program Studi Teknik Sipil, Fakultas Teknik, Universitas Muhammadiyah Yogyakarta (2014)

11. Peprah, C., Amponsah, O. \& Oduro, C., A System View of Smart Mobility and Its Implications for Ghanaian Cities. Sustainable Cities and Society, Volume 44 (2019), p. 739-747 (2019)

12. Frankhauser, P., Tannier, C., Vuidel, G. \& Houot, H.,. An Integrated Multifractal Modelling to Urban and Regional Planning. Computers, Environment and Urban Systems, Volume 67, January 2018, pp. 132-146 (2018)

13. Long, Y.,. Big/Open Data for Urban Management. Journal of Urban Management, Volume 4 (2015), p. 73 (2015)

14. Lai, S.-K., Toward A General Theory of Cities. Journal of Urban Management, Volume 7 (2018), pp. 43-45 (2018)

15. Longo, A., M. Z. \& Navathe, S. B., The Unified Chart of Mobility Services: Towards A Systemic Approach to Analyze Service Quality in Smart Mobility Ecosystem. Journal of Parallel and Distributed Computing, Volume 127, May 2019, pp. 118-133 (2019)

16. Berdica, K., An Introduction to Road Vulnerability: What Has Been Done, is Done and Should Be Done. Journal Transport Policy, Volume 9 (2002), pp. 117127 (2002)

17. Parker, S. A., Guide to Planning Resources on Transportation and Hazards. Transportation Research Board of The National Academies, Transit Cooperative Research Program (2009)

18. Jenelius, E., User Inequity Implications of Road Network Vulnerability. Journal of Transport and Land Use, Volume 2 (3/4) [Winter 2010], p. 57-73 (2010)

19. Morellia, V. G. et al., Towards IntelligentlySustainable Cities?. Journal of Land Use, Mobility and Environment, Volume 1 (2013), pp. 73-86 (2013)

20. Mudjanarko, S. W., Perencanaan Transportasi Kota. Surabaya: Program Studi Teknik Sipil, Fakultas Teknik Universitas Narotama (2016)

21. M. Lemos, C., Agent-Based Modeling of Social Conflict, From Mechanisms to Complex Behavior. s.l.:Springer Witherick, M., Ross, S., and Small, J., 2001, A Modern Dictionary of Geography (4th edition), New York: Oxford University Press (2018)

22. Chen, J. et al., What Makes The Difference in Construction Carbon Emissions between China and USA?. Sustainable Cities and Society, Volume 44, January 2019, pp. 604-613 (2019)

23. Marzanoa, G., Lizutb, J. \& Siguencia, L. O., Crowdsourcing Solutions for Supporting Urban
Mobility. Procedia Computer Science, Volume 149 (2019), p. 542-547 (2019)

24. Maerivoeta, S. et al., A Field Trial on Smart Mobility. Procedia - Social and Behavioral Sciences, Volume 54 ( 2012 ), p. 926 - 935 (2012)

25. Adirinekso, G. P., Karakteristik Penggunaan Pelaku Perjalanan Dalam Pemilihan Moda Transportasi Pekerja di Kota Jakarta Barat. Jurnal Riset Manajemen dan Bisnis, Volume 11, No. 1, Juni 2016, pp. 73-89 (2016)

26. Batty, M. \& Marshall, S., Thinking Organic, Acting Civic: The Paradox of Planning for Cities in Evolution. Landscape and Urban Planning, Volume 166 (2017), p. 4 - 14 (2017)

27. lrawati, I., Herman, Wigunawan, D. \& Rahardjoa, T. D., Solusi Pemecahan Masalah Transportasi Di Kota Bandung Berdasarkan Pendapat Pakar. Bandung, Lembaga Penelitian dan Pengabdian Kepada Masyarakat (LPPM). (2012)

28. Hu, X., J. W. \& Wang, L., Understanding the Travel Behavior of Elderly People in the Developing Country: A Case Study of Changchun, China. Social and Behavioral Sciences, Volume 96 ( 2013 ), p. 873 - 880 (2013)

29. Dacko, S. G. \& Spalteholz, C., Upgrading the City: Enabling Intermodal Travel Behaviour. Technological Forecasting \& Social Change, Volume 89 (2014), p. 222-235 (2014)

30. Ding, H., Yang, M., Wang, W. \& C. X., Simulating and Analyzing the Effect on Travel Behavior of Residential Relocation and Corresponding Traffic Demand Management Strategies. Korean Society of Civil Engineers, Journal of Civil Engineering, Volume (2018) 22(2), pp. 837-849 (2017)

31. Campos, W. G. \& Schoereder, J. H., Ecology, Behavior and Bionomics, Comparison of the Efficiency of Flight-Interception Trap Models for Sampling Hymenoptera and Other Insects. Anais da Sociedade Entomológica do Brasil, Volume 29(3), pp. 381-389 (2000)

32. Zahedi, S., Batista-Foguet, J. M. \& Wunnik, L. v., Exploring the Public's Willingness to Reduce Air Pollution and Greenhousegas Emissions from Private Road Transport in Catalonia. Science of the Total Environment, Volume 646 (2019), p. 850-861 (2018)

33. Perraa, V.-M., Sdoukopoulosa, A. \& PitsiavaLatinopoulou, M., Evaluation of Sustainable Urban Mobility in The City of Thessaloniki. Transportation Research Procedia, Volume 24 (2017), p. 329-336 (2016)

34. Carlow, V. M., Limits-Urban Density and Mobility Networks in West Berlin during the Period of Containment. Sustainability, Volume 6, pp. 74527465 (2014)

35. Zwierzchowska, I. et al., Introducing Nature-Based Solutions Into Urban Policy - Facts and Gaps. Case 
Study of Poznań. Land Use Policy, Volume 85 (2019), pp. 161-175 (2019)

36. Zhou, H. \& Gao, H., The Impact of Urban Morphology on Urban Transportation Mode: A Case Study of Tokyo. Case Studies on Transport Policy (2019)

37. Zhen, F. et al., Analyzing Urban Development Patterns Based on The Flow Analysis Method. Cities, Volume 86, March 2019, pp. 178-197 (2019)

38. Conway, T. M., Almas, A. D. \& Coore, D., Ecosystem Services, Ecological Integrity, and Native Species Planting: How to Balance tThese Ideas in Urban Forest Management?. Urban Forestry \& Urban Greening, Volume 41, May 2019, pp. 1-5 (2019)

39. Mahauta, V. \& Andrieub, H., Relative Influence of Urban-Development Strategies and Water Management on Mixed (Separated and Combined) Sewer Overflows in The Context of Climate Change and Population Growth: A Case Study in Nantes. Sustainable Cities and Society, Volume 44, January 2019, pp. 171-182 (2019)

40. Putra, P. D., Pendekatan Bionomic Pelaku Transportasi Pada Sistem Jaringan Jalan. Yogyakarta: Universitas Gadjah Mada (Unpublished Doctoral Thesis Proposal) (2021)

41. Gusnita, D., Green Transport: Transportasi Ramah Lingkungan Dan Kontribusinya Dalam Mengurangi Polusi Udara. Berita Dirgantara, Volume 11 No. 2 Juni 2010:, pp. 66-71 (2010) 